\title{
Calcitonin receptor expression in medullary thyroid carcinoma
}

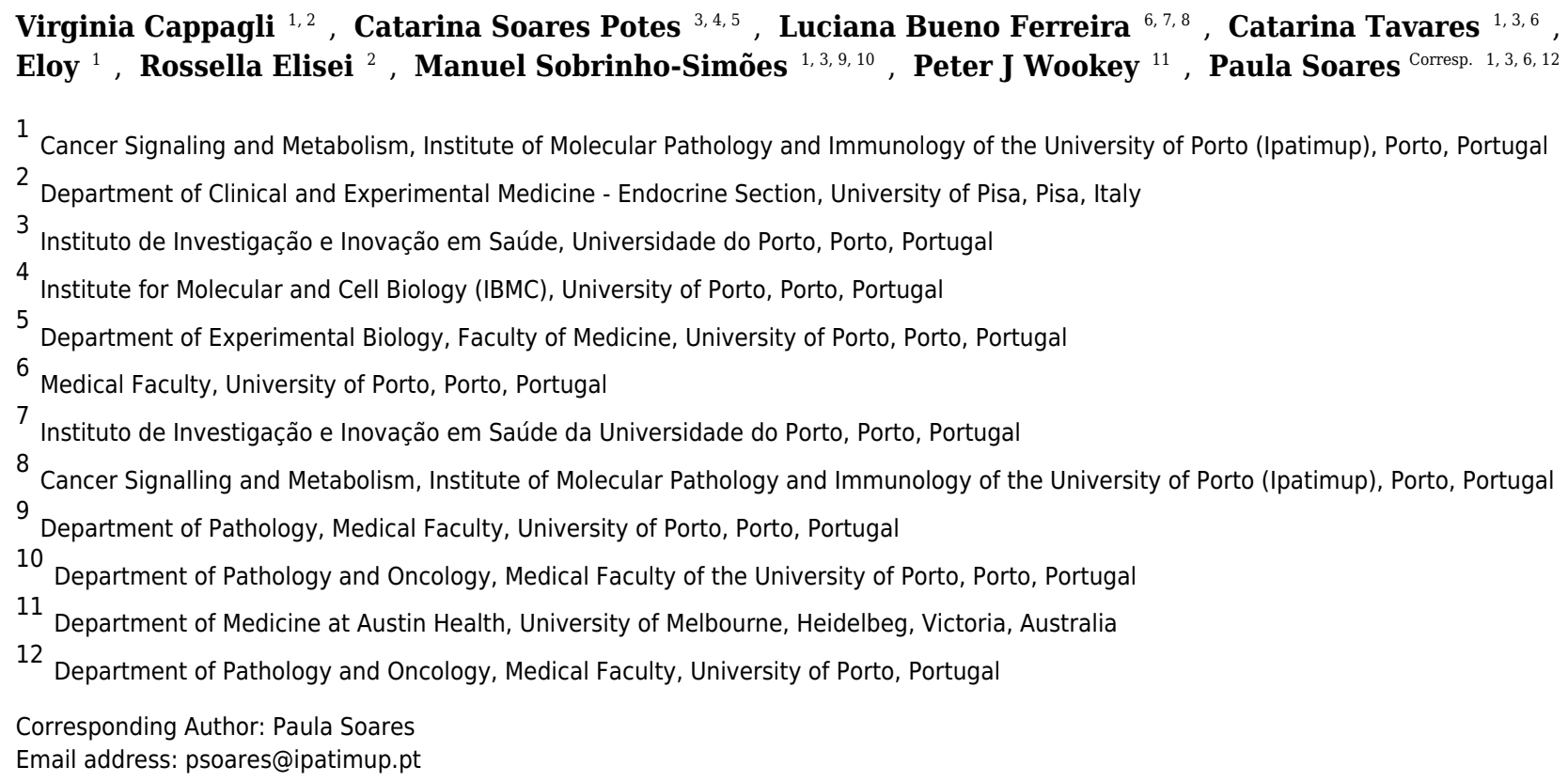

Background : Calcitonin expression is a well-established marker for medullary thyroid carcinoma (MTC); yet the role of Calcitonin receptor (CTR), its seven-transmembrane Gprotein coupled receptor, remains to be established in C-cells derived thyroid tumors. The aim of this work was to investigate CTR expression in MTC and to correlate such expression with clinicopathological features in order to evaluate its possible role as a prognostic indicator of disease aggressiveness and outcome. Methods : CTR expression was nalyzed in a series of 75 MTCs by immunohistochemistry, and by qPCR mRNA quantification in specimens from 4patients. Statistical tests were used to evaluate the correlation between CTR expression, and the clinicopathological and molecular characteristics ofpatients and tumors. Results : CTR expression was detected in 62 out of 75 samples $(82.7 \%)$, whereas 13 of the 75 samples (17.3\%) were completely negative. CTR expression was significantly associated with expression of cytoplasmatic phosphatase, tensin homologue deleted on chromosome 10 (PTEN) and osteopontin (OPN), as well as with wild type RET/RAS genes and absence of tumor stroma, suggesting that CTR expression do not associate with clinicopathological signs of worse prognosis. Discussion : CTR expression appears to be associated in MTC with more differentiated status of the neoplastic cells. 


\section{Calcitonin receptor expression in medullary thyroid carcinoma}

2 Virginia Cappagli 2,4*, Catarina Soares Potes ${ }^{1,6,7 *}$, Luciana Bueno Ferreira ${ }^{1,2,3}$, Catarina Tavares

3 1,2,3 , Catarina Eloy ${ }^{2}$, Rossella Elisei ${ }^{4}$, Manuel Sobrinho-Simões ${ }^{1,2,3,5,9}$, Peter J. Wookey ${ }^{8}$, Paula

4 Soares $^{1,2,3,9 \# .}$

5 Instituto de Investigação e Inovação em Saúde, Universidade do Porto, Porto, Portugal; ${ }^{2}$ Institute

6 of Molecular Pathology and Immunology of the University of Porto (Ipatimup) - Cancer Signaling

7 and Metabolism, Porto, Portugal; ${ }^{3}$ Medical Faculty, University of Porto, Porto, Portugal;

$8{ }^{4}$ Department of Clinical and Experimental Medicine - Endocrine Section, University of Pisa, Pisa,

9 Italy; ${ }^{5}$ Hospital de S. João, Department of Pathology Porto, Portugal; ${ }^{6}$ Institute for Molecular and

10 Cell Biology (IBMC), University of Porto, Porto, Portugal, ${ }^{7}$ Department of Biomedicine -

11 Experimental Biology Unit, Faculty of Medicine, University of Porto, Porto, Portugal;

$12{ }^{8}$ Department of Medicine at Austin Health, University of Melbourne, Australia; ${ }^{9}$ Medical Faculty,

Department of Pathology and Oncology, University of Porto, Porto, Portugal.

*Both authors contributed equally to the work

\# Correspondence should be addressed to Paula Soares,

17 Email: psoares@ipatimup.pt

Institute of Molecular Pathology and Immunology, University of Porto

Rua Dr. Roberto Frias, s/n 4200-465 Porto, Portugal

Short title: calcitonin receptor expression in MTC 


\section{ABSTRACT}

Background: Calcitonin expression is a well-established marker for medullary thyroid carcinoma (MTC); yet the role of Calcitonin receptor (CTR), its seven-transmembrane G-protein coupled receptor, remains to be established in C-cells derived thyroid tumors. The aim of this work was to investigate CTR expression in MTC and to correlate such expression with clinicopathological features in order to evaluate its possible role as a prognostic indicator of

32 disease aggressiveness and outcome.

Methods: CTR expression was analyzed in a series of 75 MTCs by immunohistochemistry, and by qPCR mRNA quantification in specimens from 4 patients. Statistical tests were used to evaluate the correlation between CTR expression, and the clinicopathological and molecular characteristics of patients and tumors. 75 samples (17.3\%) were completely negative. CTR expression was significantly associated with expression of cytoplasmatic phosphatase, tensin homologue deleted on chromosome 10 (PTEN) and osteopontin (OPN), as well as with wild type $R E T / R A S$ genes and absence of tumor stroma, suggesting that CTR expression do not associate with clinicopathological signs of worse prognosis.

43 status of the neoplastic cells. 


\section{INTRODUCTION}

45 Medullary thyroid carcinoma (MTC) is a rare tumor representing 5-10\% of thyroid cancers (Elisei et al. 2013). It is a tumor with neuroendocrine differentiation and arises from the parafollicular Ccells of the thyroid which normally secrete calcitonin (CT). MTC originates as a sporadic (75$80 \%$ ) malignancy or a manifestation of hereditary syndromes $(20-25 \%)$, i.e. multiple endocrine neoplasia type 2 (MEN2A or MEN2B) / familial MTC, with an autosomal dominant pattern due

to germline mutations of the RET gene (Pacini et al. 2010). In both forms of MTC (sporadic and familial) the clinic-laboratorial diagnosis is based mainly on the finding of elevated levels of serum diagnosing MTC, even though some other pathological/physiological conditions can be associated with increased levels of that hormone (Elisei et al. 2013). The clinical behavior of MTC is less favorable compared to follicular cell-derived thyroid tumors: 10-year survival rate is about 50$75 \%$ and the most important prognostic factor is tumor stage at diagnosis (Elisei et al. 2013; Kloos et al. 2009).

CT is a polypeptide hormone of 32 amino acids which is involved in the regulation of calcium homeostasis (Muff et al. 2004; Wimalawansa 1997) under conditions of hypercalcaemia

60 (Turner et al. 2011). It has been shown the osteoanabolic action of CT (Keller et al. 2014). CT has also been implicated in protecting the skeleton from excessive loss of bone during periods of high calcium demand, such as lactation (Davey \& Findlay 2013). In experimental models CT secretion was inhibited by high levels of CT suggesting a possible negative feedback mechanism (as for other endocrine system molecules) and autocrine regulation of normal C- cells (Kakudo et al. 1989; Morimoto et al. 1984; Orme \& Pento 1976). 
CT binds specific calcitonin receptors (CTR) that belong to the family B of G-protein

67

68

coupled receptors (GPCRs) (Chakraborty et al. 1991; Conner et al. 2002; Lin et al. 1991; Poyner et al. 2002). In mammals, CTR is widely expressed during blastula implant and during fetal (Jagger et al. 2000; Pondel 2000; Tolcos et al. 2003) and perinatal (Tikellis et al. 2003; Wookey et al. 2012b) development. In adult tissues, CTR is widely expressed, for example in neural networks (Becskei et al. 2004; Sexton et al. 1988), in osteoclasts and osteocytes (Gooi et al. 2010), renal distal epithelium, B and T-cells (Body et al. 1990; Cafforio et al. 2009), testis, lung (FouchereauPeron et al. 1981) and several other tissues (reviewed in (Findlay 2006; Wookey et al. 2010)). CTR is also expressed by specific cell types in wound healing (Wookey et al. 2010), in cardiovascular diseases (Wookey et al. 2008; Wookey et al. 2009) and in several types of malignant tissues as breast (Gillespie et al. 1997) and prostate cancer (Thomas et al. 2006), as well as in cell lines derived from neoplasias of the lung (Findlay et al. 1980; Findlay et al. 1989), breast (Findlay et al. 1981; Gillespie et al. 1997; Kuestner et al. 1994), brain (Wookey et al. 2012a), bone osteoclasts (Gorn et al. 1995; Nicholson et al. 1987), prostate (Thomas et al. 2007), and of lymphoid (Marx et al. 1974) and myeloid tissues (Gattei et al. 1992; Silvestris et al. 2008).

CTR is the only receptor for CT characterized to date, and serves also as the signaling protomer for the heteromeric amylin receptor (CTR/RAMP-1). A unifying physiological role for CTR and its ligands in the previously mentioned situations remains to be advanced.

CTR function is best characterized as coupling to the stimulatory $\mathrm{G} \alpha$ subunit $(\mathrm{G} \alpha \mathrm{S})$ to increase adenylate cyclase (cAMP) activity and to activate downstream cAMP sensors PKA and Epac but has also been shown to couple to intracellular calcium mobilization and extracellular regulated kinase (ERK) phosphorylation. In humans, two different isoforms of CTR, generated by alternative splicing, have been reported. These two forms differ by an insert of 16 amino acids in 
89 the first intracellular loop (CTR C1b $\left[\mathrm{I}^{+}\right.$, insert ${ }^{+}$, 483 amino acids while $\mathrm{CTR} \mathrm{C}_{1 \mathrm{a}}\left[\mathrm{I}^{-}\right.$, insert $\left.{ }^{-}\right]$is

90467 amino acids in length) (Frendo et al. 1994; Gorn et al. 1992; Kuestner et al. 1994). in thyroid cell lines (TT cell line derived from MTC) and in two MTC cases (Frendo et al. 1994). In subsequent studies Frendo et al showed that CTR C1a mRNA was present in both normal and

94 tumoral MTC thyroid tissue. No differences were found between sporadic and familial MTC regarding the expression of CTR C1a mRNA (Frendo et al. 1998a; Frendo et al. 1998b). Higher expression of CTR C1a mRNA was found in MTC samples compared with normal tissue, and it was also reported that CTR C1a mRNA levels were modified during cell proliferation (Frendo et al. 1998b). The putative function of CTR in malignant tissues and tumor cell lines are still largely unknown and different results have been reported according to the different affected tissue. In breast cancer cell lines, there is evidence of an anti-proliferative effect of CTR activation (Nakamura et al. 2007; $\mathrm{Ng}$ et al. 1983), while in prostate cancer the up-regulation of the CT/CTR axis seems to help the switch of prostate cells towards a malignant phenotype (Thomas et al. 2006; Thomas et al. 2007) stimulating proliferation, metastization and angiogenesis.

There are no studies evaluating levels of expression of CTR protein on MTC. Furthermore, no association between CTR mRNA or serum CT levels with the clinical characteristics or the prognosis of the patients with MTC have been reported (Frendo et al. 1998b). Given the lack of data regarding protein expression and the possible role of CTR in MTC, we decided to evaluate the expression of CTR protein in a large series of MTC and to correlate the expression level with molecular and clinicopathological features.

\section{MATERIALS AND METHODS}

\section{Human MTC Tissue Samples}


A total of 75 MTC samples diagnosed in two institutions were used in the present study.

114 Formalin-fixed, paraffin-embedded tissue and the corresponding clinical data were retrieved from

115 the files of the Centro Hospitalar S. João (CHSJ)/Medical Faculty of Porto (FMUP)/Ipatimup (55

116 cases) and the Portuguese Institute of Oncology, Coimbra (IPO-C) (20 cases). The diagnosis of

117 MTC was revised by two pathologists (CE and MSS) and confirmed by calcitonin

118 immunostaining. Clinicopathological and follow-up data were obtained from the surgical

119 pathology reports and patients' records of the Department of Pathology and Oncology of CHSJ

120 and from IPO database (Supplementary table). The series from Ipatimup included consultation

121 cases from which only limited demographic and clinical information was available. $R E T$ and $R A S$

122 genetic characterization of the series have been previously reported (Lyra et al. 2014). The study

123 was approved by the Hospital Ethical Committee of the Centro Hospitalar São João / Faculdade

124 de Medicina da Universidade do Porto (FMUP) (CES 284/13) and the National Ethical rules were

125 followed in every procedure.

126

127 Immunohistochemistry (IHC)

128 Immunohistochemistry for human CTR was performed in representative tumor sections of

129 the 75 MTC cases. The mouse monoclonal anti-human CTR antibody (mAb) 31/01-1H10 against

130 a cytoplasmatic epitope within the carboxyl terminal of human CTR (DIPIYICHQELRNEPANN;

131 Welcome Receptor Antibodies Pty Ltd (WRA), Melbourne; also distributed as MCA2191 by

132 BioRad AbD Serotec) was used, which was already characterized in previous studies (Silvestris et

133 al. 2008; Wookey et al. 2012a; Wookey et al. 2008; Wookey et al. 2009). Deparaffinized and

134 rehydrated sections were subjected to microwave treatment in $10 \mathrm{mM}$ sodium citrate buffer, $\mathrm{pH}$

135 6.0, for antigen retrieval. After blocking, the sections were incubated overnight at $4^{\circ} \mathrm{C}$ in a 
136 humidified chamber with the primary antibody anti-CTR (mAb 31/01-1H10 1:4000). For the

137 detection, a labelled streptavidin-biotin immunoperoxidase detection system was employed

138 (Thermo Scientific/Lab Vision, Fremont, USA), and the immunohistochemical staining was

139 developed with 3,3'-diaminobenzidine substrate. A negative control consisting on the omission of

140 the primary antibody was performed. IHC evaluation was performed independently by two

141 observers (CE and VC). CTR expression was evaluated taking into account the proportion of 142 positive stained cells (scored as $\leq 5 \%=0 ; 5-25 \%=1 ; 25-50 \%=2,50-75 \%=3$ and $75-100 \%=$

143 4) and the staining intensity (scored as absent $=0$, faint $=1$, moderate $=2$ and strong $=3)($ Table

144 1). CTR expression was semi-quantified using a staining score (from 0 to 12 ) corresponding to the 145 multiplication of the staining intensity by the proportion of positive stained cells (Table 2) as 146 previously described by our group (Ferreira et al. 2016; Lyra et al. 2014). CTR expression was 147 correlated with data previously obtained by our group in this series of tumors with regard to 148 phosphatase and tensin homologue deleted on chromosome 10 (PTEN), phospho-S6 ribosomal 149 protein (pS6) (Lyra et al. 2014) and osteopontin (OPN) IHC expression (Ferreira et al. 2016).

CT staining with a rabbit monoclonal antibody (ref.: RM-9117-S, clone SP17,

151 Neomarkers) was performed for diagnostic purposes and CT immune-expression was semi152 quantified, based on the intensity of the staining, in a score from 1 to 4 . In the majority of the cases 153 the staining of CT and CTR was done in serial sections. The CT score obtained was correlated 154 with the corresponding CTR expression score in each case (64/75 cases; in 11 cases we do not 155 have access to the calcitonin staining slides).

\section{RNA extraction and reverse transcription}

Total RNA was extracted from frozen specimens of MTC $(n=4)$, from adjacent normal 
159 tissue specimens $(\mathrm{n}=5)$ and from two MTC-derived cell lines (TT, purchased from American

160 Type Culture Collection - ATCC; and MZ-CRC-1, provided by Dr Robert Hofstra, Netherlands)

161 using a Trizol commercial kit (Life Technologies, GIBCO BRL, Carlsbad, CA) according to the

162 manufacturer's protocol. RNA was quantified by spectrophotometry, and its quality was checked

163 by analysis of $260 / 280 \mathrm{~nm}$ and $260 / 230 \mathrm{~nm}$ ratios. For cDNA preparation, $1 \mu \mathrm{g}$ of total RNA was

164 reverse transcribed using the RevertAid first strand cDNA synthesis kit (Fermentas, Burlington, 165 ON, Canada).

166

167

168

169

170

171

172

173

174

175

176

177

178

179

180

181

\section{Real Time PCR}

Reverse transcription products of CTR were amplified by real-time quantitative PCR (IDT, \#HS.PT.56a.40988589) using TaqMan ${ }^{\circledR}$ PCR Master Mix (Applied Biosystems, Foster City, CA, USA) with TBP gene (TATA-binding protein) as endogenous control (Applied Biosystems, \#4326322E-0705006). The ABI PRISM 7500 Fast Sequence Detection System (Applied Biosystems) was used to detect the amplification level and was programmed to an initial step of 2 minutes at $50^{\circ} \mathrm{C}, 10$ minutes at $95^{\circ} \mathrm{C}$, followed by 45 cycles of $95^{\circ} \mathrm{C}$ for 15 seconds and $60^{\circ} \mathrm{C}$ for 1 minute. The relative quantification of target genes was determined using the $\Delta \Delta \mathrm{CT}$ method which was previously validated by Livak's Linear Regression Method (Slope=0.0696) (Sequence Detector User Bulletin 2, Applied Biosystems). Primers used for qPCR are available at the manufacturer's website.

\section{Statistical Analysis}

Statistical analysis was performed using 22.0 SPSS statistical package (IBM, 2014). The relationship between the immunohistochemical score of CTR and clinicopathological features was 
182 evaluate by independent sample t-test or Mann Whitney test (for comparisons of groups having

183 less than 30 cases). The correlation between the immunoreactivity of the other proteins (PTEN,

184 pS6, OPN and CT) with CTR was assessed using the Pearson correlation test. A p-value $\leq 0.05$

185 was considered statistically significant.

186

187 RESULTS

188 CTR protein expression in MTC

189 CTR expression was mainly localized in the cytoplasm and was detected in 62 out of 75 190 samples $(82.7 \%)$, while the remaining 13 samples $(17.3 \%)$ were negative. In the 62 positive 191 samples, CTR expression was present in more than $50 \%$ of the cells in 55 cases $(88.7 \%)$ (Table 1$)$ 192 and the staining intensity was faint in $34.7 \%$, moderate in $25.3 \%$ and strong in $25.3 \%$ (Table 1 ).

193 The distribution of the staining score among the positive cases is present in Table 2. In a few cases, 194 scattered nuclear staining was observed. Examples of representative cases and the negative 195 controls are shown in Figure 1 (additional staining patterns are shown in Supplementary Figure 1).

\section{Correlation of CTR expression with clinicopathological and molecular features of MTC}

No significant associations were observed between CTR expression and age of the patients, tumor dimension, lymph node and/or distant metastasis, tumoral invasion nor extrathyroidal 200 extension (Table 3). Tumors from female patients had significantly higher CTR expression (Table 201 $3)$.

The characteristics of the tumoral stroma were evaluated separately, accounting for the presence of either an amyloid stroma or a hyaline/desmoplastic stroma versus the absence of any 
205 CTR (7.9 vs 5.5, $\mathrm{p}=0.04$ ) than tumors presenting hyaline/desmoplastic stroma, while there was no 206 correlation with the presence/absence of an amyloid stroma.

Tumors wild-type for $R A S$ or RET genes had higher CTR expression when compared to

208

209

210

211

212

213

214

215

216

217

218

219

220

221

222

223

224

225

226

227 mutated cases ( 7.3 vs $5.2, p=0.04$; Table 2 ). The same trend was observed when these mutations were analyzed separately but the differences did not reach statistical significance $(\mathrm{p}=0.07$, for $R A S$ positive cases versus wild-type for both mutations and $\mathrm{p}=0.09$ for $R E T$-positive tumors versus tumors wild-type for both mutations).

There was a strong positive correlation between CT staining and CTR expression, $(p=0.001)$, that is, the cases with higher score for CT staining showed also higher CTR expression (Figure 2).

The immunohistochemical detection of other cancer related proteins such as PTEN, pS6 and OPN had been previously analyzed in the same series of MTCs (Lyra et al. 2014) (Ferreira, et al. 2016). In this study we evaluated the relationship between the expression of those markers with CTR expression. Tumors with cytoplasmatic PTEN expression presented significantly higher CTR expression compared to PTEN cytoplasmatic negative cases $(p=0.038)$. There was also a significant association between OPN expression and CTR expression $(p=0.009)$. No correlation was found between CTR and pS6 expression $(\mathrm{p}=0.21)$.

\section{CTR mRNA expression in MTC}

CTR mRNA levels were analyzed in 4 cases of MTC and adjacent non-tumoral thyroid tissue from which frozen samples were available, and also in two MTC-derived cell lines (TT and MZ-CRC-1). A similar expression of CTR mRNA was observed in adjacent thyroid tissue and MTC (Figure 1) except in one case in which a much higher expression was observed in the tumor 
228 than in the respective adjacent thyroid parenchyma. We must emphasize that the low number of

229 C-cells present in adjacent normal parenchyma limits this analysis. Both MTC-derived cell lines

230 expressed CTR mRNA (Figure 3); the expression was higher in TT cell line than in MZCRC1 (TT

$231=0.498658$ versus $\mathrm{MZCRC} 1=0.1280699)$.

232

233

\section{DISCUSSION}

This is the first study in which expression levels of CTR protein were evaluated in a large series of MTC cases. The study of the expression of CTR mRNA and of the function of CT/CTR in MTC is limited to few papers that analyzed a limited number of cases (Frendo et al. 1998a; Frendo et al. 1998b; Frendo et al. 1994). In the present study the expression of CTR protein was evaluated in 75 MTC cases and this information was used to search for correlations with MTC cases.

At variance with the results obtained in other tumor models, in our series high levels of CTR protein expression did not correlate with poor prognosis or aggressive features of MTC. On the contrary, there was a tendency for CTR to be more expressed in smaller tumors, without capsular or vascular invasion and without distant metastasis. These findings could suggest that CTR expression might be associated to tumor differentiation. Further studies in large series are necessary to confirm (or not) this tendency. TT cell lines, the shorter isoform of CTR (CTR C1a) was expressed and that CTR mRNA was present both in normal and tumor tissue with higher levels in tumors and without differences among the different clinical forms of MTC (Frendo et al. 1998b). Our hypothesis that higher 
251 expression of CTR in MTC may be associated with a more differentiated status of the neoplastic

252 cells is consistent with the demonstration that inhibition of proliferation of the TT cell line

253 correlated with increased expression and secretion of CT (deBustros et al. 1986). The expression

254 of CTR mRNA in two MTC derived cell lines open the possibility of further functional studies

255 with siRNA to evaluate in vitro the consequences of CTR gene silencing in the differentiation of

256 MTC cells. The close homology between several molecules: CT/CTR (independent of RAMPs),

257 amylin receptors with CTR/RAMPs 1, 2 or 3 and, CGRP receptors defined by CTR/RAMP 2 (as

258 well as CRLR/RAMP 1) can, however, be a limiting factor in those studies.

259 We must also consider the possibility of transient epithelial-mesenchymal transition (EMT)

260 as it was recently reported by Johansson et al (Johansson et al. 2015) in MTC where

261 "differentiation genes" are repressed in locally invasive tumor cells but re-expressed at metastatic

262 sites. In this sense it will be also very interesting to explore the expression of CTR in primary and

263 metastatic MTC lesions, as well as in the invasive front $v s$ tumor bulk, in combination with lineage

264 specific markers (Foxa1/Foxa2) and epithelial-mesenchymal transition markers.

265 In our hands, CTR expression correlated with CT expression at the protein (IHC) level. Taken 266 together, these data fit with the assumption that a more differentiated MTC status, as evaluated by

267 CT levels, is associated with elevated expression of CTR (Figure 2).

268 There seems to be an association of OPN expression and a more differentiated MTC status.

269 Briese et al (Briese et al. 2010) demonstrated a higher expression of the OPN protein in MTC than

270 in normal thyroid. Our group confirmed this association through the finding that OPN is correlated

271 with features of better prognosis of MTC and with C-cell differentiation (Ferreira et al. 2016).

272 OPN is a matricellular glycoprotein involved in biological processes, as biomineralization, bone 273 remodeling and immune responses, and also in pathological processes. In the present study we 
274 found a strong positive correlation between CTR expression and OPN expression and this finding

275 reinforces the hypothesis that CTR is probably related with C-cell differentiation.

PTEN is a phosphatase enzyme and acts as tumor suppressor with different functions

277

278

279

280

281

282

283

284

285

286

287

288

289

290

291

292

293

294

295

296

according to its subcellular localization (Bononi \& Pinton 2015; Chung \& Eng 2005). PTEN is an important down-regulator of Akt/mTOR, a pathway that is involved in MTC tumorigenesis (Tamburrino et al. 2012). In a previous study of our group (Lyra et al. 2014) we proposed that, in MTCs, $R A S$ mutation plays a direct role in the activation of mTOR pathway, while in $R A S$ wild type tumors the mTOR pathway appear to be activated by a mechanism involving a lower expression of cytoplasmatic PTEN. In the present, study we observed that higher expression of CTR correlated with higher cytoplasmic PTEN expression in MTC. In accordance with our previous results we found that tumors that were wild-type for $R A S$ or $R E T$ had significantly higher CTR expression when compared to mutated tumors. Further studies are necessary to evaluate the role of CTR in this context.

The role of stroma in the regulation of tumorigenesis is largely acknowledged (Tlsty \& Coussens 2006). The stromal reaction has been described in several tumor types and it has been related with a more invasive and aggressive tumor behavior in most of such models (Rowley 1998). This holds particularly true in MTC in which several studies (Koperek et al. 2008; Scheuba et al. 2006) have associated the presence of a "hyaline/desmoplastic" stroma with more aggressive features (tumor size, tumor stage, more invasive tumors and the presence of lymph node metastasis). In the present series, we observed a significantly higher expression of CTR in cases without or with discrete tumor stroma. Putting these results together we think that our results reinforce the idea that CTR may be a marker of better differentiation, less invasive and less aggressive tumors. 
The CT/CTR axis in tumors is not well understood and the studies on record report

298 dissimilar data according to different tumor models. In prostate, several studies (Chigurupati et al. 2005; Shah et al. 2009; Thakkar et al. 2013; Thomas et al. 2006; Thomas et al. 2007), using primary

300 tumor samples and cell lines, suggested a tumorigenic role of CTR. In particular, it was

301 demonstrated that there was a different spatial expression between normal and tumor tissue with

302 an higher expression in the tumors and that, while in the early stage of prostate cancer the tumor

303 cells expressed either CT or CTR, in the advanced cases there was a co-expression of both and

304 such co-expression associated with a metastatic phenotype (Thakkar et al. 2013). Furthermore, a

305 higher expression of CT/CTR correlated with a higher tumor grade and a worsen prognosis

306 (Thakkar et al. 2013). In prostate cancer, the most important pathway upregulated through CTR

307 activation is cAMP, leading to a higher invasiveness due to the degradation of extracellular matrix

308 by PKA and urokinase-plasminogen A system (Thomas et al. 2006). In contrast to this, in breast

309 cancer, CT/CTR seems to play a protective role as $\mathrm{Ng}$ and colleagues showed that CT was able to

310 inhibit the growth of a breast cancer cell line ( $\mathrm{Ng}$ et al. 1983). In subsequent studies, other groups

311 (Gillespie et al. 1997; Wang et al. 2004) demonstrated that CTR, mostly the isoform 2, was

312 expressed in tumor samples and cell lines and that a decreased CTR expression was observed in

313 advanced tumors with lymph node metastases and lymphatic invasion. Finally, CTR was shown

314 to be involved in the control of breast cancer invasion by down-regulating the activity of urokinase-

315 plasminogen A and inhibiting cells invasiveness in a concentration-dependent manner (Han et al.

316 2006). Our results regarding the CTR expression in MTC and its correlation with patients'

317 prognosis are more alike the breast cancer model, namely regarding the tendency for CTR to be

318 more expressed in smaller tumors, without invasion and metastasis. Unfortunately, data

319 concerning the final outcome of the patients was only available in 20 out of the 75 cases and this 
320 represents a major limitation. From these 20 cases 13 were CTR-positive (65\%) and 7 were CTR-

321 negative (35\%). Considering the outcome of the patients, seven out of 20 patients are free of disease

322 being 5 CTR-positive (71\%) and 2 CTR-negative (29\%) whereas in the group of the five patients

323 that died due to the disease, $2(40 \%)$ were CTR-positive and $3(60 \%)$ were CTR-negative. This

324 tendency to lower CTR expression in patients with guarded prognosis needs to be verified in a

325 larger MTC series.

326

327 CONCLUSIONS

328 In summary, the present study confirms that CTR is expressed in most MTCs and our data 329 seems to suggest that CTR expression in MTCs is associated with a more differentiated status and 330 clinical and molecular features of good prognosis. Further studies are needed to clarify the function 331 of CTR in normal and tumoral C-cells.

332

333

334 


\section{References}

Becskei C, Riediger T, Zund D, Wookey P, and Lutz TA. 2004. Immunohistochemical mapping of calcitonin receptors in the adult rat brain. Brain Res 1030:221-233.

Body JJ, Glibert F, Nejai S, Fernandez G, Van Langendonck A, and Borkowski A. 1990. Calcitonin receptors on circulating normal human lymphocytes. J Clin Endocrinol Metab 71:675-681.

Bononi A, and Pinton P. 2015. Study of PTEN subcellular localization. Methods 77-78:92-103. S10462023(14)00319-3 [pii] 10.1016/j.ymeth.2014.10.002

Briese J, Cheng S, Ezzat S, Liu W, Winer D, Wagener C, Bamberger AM, and Asa SL. 2010. Osteopontin (OPN) expression in thyroid carcinoma. Anticancer Res 30:1681-1688. 30/5/1681 [pii]

Cafforio P, De Matteo M, Brunetti AE, Dammacco F, and Silvestris F. 2009. Functional expression of the calcitonin receptor by human T and B cells. Hum Immunol 70:678-685. S0198-8859(09)00134-7 [pii]10.1016/j.humimm.2009.05.005

Chakraborty M, Chatterjee D, Kellokumpu S, Rasmussen H, and Baron R. 1991. Cell cycle-dependent coupling of the calcitonin receptor to different G proteins. Science 251:1078-1082.

Chausmer A, Stuart C, and Stevens M. 1980. Identification of testicular cell plasma membrane receptors for calcitonin. J Lab Clin Med 96:933-938. 0022-2143(80)90141-9 [pii]

Chigurupati S, Kulkarni T, Thomas S, and Shah G. 2005. Calcitonin stimulates multiple stages of angiogenesis by directly acting on endothelial cells. Cancer Res 65:8519-8529. 65/18/8519 [pii]10.1158/0008-5472.CAN-05-0848

Chung JH, and Eng C. 2005. Nuclear-cytoplasmic partitioning of phosphatase and tensin homologue deleted on chromosome 10 (PTEN) differentially regulates the cell cycle and apoptosis. Cancer Res 65:8096-8100. 65/18/8096 [pii]10.1158/0008-5472.CAN-05-1888

Conner AC, Hay DL, Howitt SG, Kilk K, Langel U, Wheatley M, Smith DM, and Poyner DR. 2002. Interaction of calcitonin-gene-related peptide with its receptors. Biochem Soc Trans 30:451-455. 10.1042/

Davey RA, and Findlay DM. 2013. Calcitonin: physiology or fantasy? J Bone Miner Res 28:973-979. 10.1002/jbmr.1869

deBustros A, Baylin SB, Levine MA, and Nelkin BD. 1986. Cyclic AMP and phorbol esters separately induce growth inhibition, calcitonin secretion, and calcitonin gene transcription in cultured human medullary thyroid carcinoma. J Biol Chem 261:8036-8041.

Elisei R, Alevizaki M, Conte-Devolx B, Frank-Raue K, Leite V, and Williams GR. 2013. 2012 European thyroid association guidelines for genetic testing and its clinical consequences in medullary thyroid cancer. Eur Thyroid J 1:216-231. 10.1159/000346174etj-0001-0216 [pii]

Ferreira LB, Eloy C, Pestana A, Lyra J, Moura M, Prazeres H, Tavares C, Sobrinho-Simoes M, Gimba E, and Soares P. 2016. Osteopontin expression is correlated with differentiation and good prognosis in medullary thyroid carcinoma. Eur J Endocrinol 174:551-561. 10.1530/EJE-15-0577EJE-15-0577 [pii]

Findlay DM. 2006. Regulation of cell growth mediated by the calcitonin receptor. Cell Mol Biol (Noisy-legrand) 52:3-8.

Findlay DM, deLuise M, Michelangeli VP, Ellison M, and Martin TJ. 1980. Properties of a calcitonin receptor and adenylate cyclase in BEN cells, a human cancer cell line. Cancer Res 40:1311-1317.

Findlay DM, Michelangeli VP, Moseley JM, and Martin TJ. 1981. Calcitonin binding and degradation by two cultured human breast cancer cell lines (MCF 7 and T 47D). Biochem J 196:513-520.

Findlay DM, Michelangeli VP, and Robinson PJ. 1989. Protein kinase-C-induced down-regulation of calcitonin receptors and calcitonin-activated adenylate cyclase in T47D and BEN cells. Endocrinology 125:2656-2663. 10.1210/endo-125-5-2656 
381

Fouchereau-Peron M, Moukhtar MS, Benson AA, and Milhaud G. 1981. Characterization of specific receptors for calcitonin in porcine lung. Proc Natl Acad Sci U S A 78:3973-3975.

Frendo JL, Delage-Mourroux R, Cohen R, Pichaud F, Pidoux E, Guliana JM, and Jullienne A. 1998a. Calcitonin receptor mRNA expression in TT cells: effect of dexamethasone. Mol Cell Endocrinol 139:37-43. S0303-7207(98)00075-6 [pii]Frendo JL, Delage-Mourroux R, Cohen R, Pichaud F, Pidoux E, Guliana JM, and Jullienne A. 1998b. Calcitonin receptor mRNA is expressed in human medullary thyroid carcinoma. Thyroid 8:141-147.

Frendo JL, Pichaud F, Mourroux RD, Bouizar Z, Segond N, Moukhtar MS, and Jullienne A. 1994. An isoform of the human calcitonin receptor is expressed in TT cells and in medullary carcinoma of the thyroid. FEBS Lett 342:214-216. 0014-5793(94)80503-2 [pii]

Gattei V, Bernabei PA, Pinto A, Bezzini R, Ringressi A, Formigli L, Tanini A, Attadia V, and Brandi ML. 1992. Phorbol ester induced osteoclast-like differentiation of a novel human leukemic cell line (FLG 29.1). J Cell Biol 116:437-447.

Gillespie MT, Thomas RJ, Pu ZY, Zhou H, Martin TJ, and Findlay DM. 1997. Calcitonin receptors, bone sialoprotein and osteopontin are expressed in primary breast cancers. Int J Cancer 73:812-815. 10.1002/(SICI)1097-0215(19971210)73:6<812::AID-IJC7>3.0.CO;2-5 [pii]

Gooi JH, Pompolo S, Karsdal MA, Kulkarni NH, Kalajzic I, McAhren SH, Han B, Onyia JE, Ho PW, Gillespie MT, Walsh NC, Chia LY, Quinn JM, Martin TJ, and Sims NA. 2010. Calcitonin impairs the anabolic effect of PTH in young rats and stimulates expression of sclerostin by osteocytes. Bone 46:14861497. S8756-3282(10)00442-4 [pii]10.1016/j.bone.2010.02.018

Gorn AH, Lin HY, Yamin M, Auron PE, Flannery MR, Tapp DR, Manning CA, Lodish HF, Krane SM, and Goldring SR. 1992. Cloning, characterization, and expression of a human calcitonin receptor from an ovarian carcinoma cell line. J Clin Invest 90:1726-1735. 10.1172/JCI116046

Gorn AH, Rudolph SM, Flannery MR, Morton CC, Weremowicz S, Wang TZ, Krane SM, and Goldring SR. 1995. Expression of two human skeletal calcitonin receptor isoforms cloned from a giant cell tumor of bone. The first intracellular domain modulates ligand binding and signal transduction. $J$ Clin Invest 95:2680-2691. 10.1172/JCl117970

Han B, Nakamura M, Zhou G, Ishii A, Nakamura A, Bai Y, Mori I, and Kakudo K. 2006. Calcitonin inhibits invasion of breast cancer cells: involvement of urokinase-type plasminogen activator (UPA) and uPA receptor. Int J Oncol 28:807-814.

Jagger C, Chambers T, and Pondel M. 2000. Transgenic mice reveal novel sites of calcitonin receptor gene expression during development. Biochem Biophys Res Commun 274:124-129.

Johansson E, Andersson L, Ornros J, Carlsson T, Ingeson-Carlsson C, Liang S, Dahlberg J, Jansson S, Parrillo L, Zoppoli P, Barila GO, Altschuler DL, Padula D, Lickert H, Fagman H, and Nilsson M. 2015. Revising the embryonic origin of thyroid C cells in mice and humans. Development 142:3519-3528. 10.1242/dev.126581

Kakudo K, Itoh J, Takekoshi S, and Watanabe K. 1989. Effects of synthetic salmon calcitonin on C cells of the thyroid. Acta Pathol Jpn 39:545-550.

Keller J, Catala-Lehnen P, Huebner AK, Jeschke A, Heckt T, Lueth A, Krause M, Koehne T, Albers J, Schulze J, Schilling S, Haberland M, Denninger H, Neven M, Hermans-Borgmeyer I, Streichert T, Breer $S$, Barvencik F, Levkau B, Rathkolb B, Wolf E, Calzada-Wack J, Neff F, Gailus-Durner V, Fuchs H, de Angelis MH, Klutmann S, Tsourdi E, Hofbauer LC, Kleuser B, Chun J, Schinke T, and Amling M. 2014. Calcitonin controls bone formation by inhibiting the release of sphingosine 1-phosphate from osteoclasts. Nat Commun 5:5215. 10.1038/ncomms6215

Kloos RT, Eng C, Evans DB, Francis GL, Gagel RF, Gharib H, Moley JF, Pacini F, Ringel MD, Schlumberger M, and Wells SA, Jr. 2009. Medullary thyroid cancer: management guidelines of the American Thyroid Association. Thyroid 19:565-612. 10.1089/thy.2008.0403 
Koperek O, Scheuba C, Cherenko M, Neuhold N, De Micco C, Schmid KW, Niederle B, and Kaserer K. 2008. Desmoplasia in medullary thyroid carcinoma: a reliable indicator of metastatic potential. Histopathology 52:623-630. HIS3002 [pii]10.1111/j.1365-2559.2008.03002.x

Kovacs C, Chafe L, Woodland M, McDonald K, Fudge N, and Wookey P. 2002. Calcitropic gene expression in the murine placenta suggests a role for the intraplacental yolk sac in maternal-fetal calcium exchange. American Journal of Physiology 282:E721-E732.

Kuestner RE, Elrod RD, Grant FJ, Hagen FS, Kuijper JL, Matthewes SL, O'Hara PJ, Sheppard PO, Stroop SD, Thompson DL. 1994. Cloning and characterization of an abundant subtype of the human calcitonin receptor. Mol Pharmacol 46:246-255.

Lin HY, Harris TL, Flannery MS, Aruffo A, Kaji EH, Gorn A, Kolakowski LF, Jr., Yamin M, Lodish HF, and Goldring SR. 1991. Expression cloning and characterization of a porcine renal calcitonin receptor. Trans Assoc Am Physicians 104:265-272.

Lyra J, Vinagre J, Batista R, Pinto V, Prazeres H, Rodrigues F, Eloy C, Sobrinho-Simoes M, and Soares P. 2014. mTOR activation in medullary thyroid carcinoma with RAS mutation. Eur $J$ Endocrinol 171:633-640. 10.1530/EJE-14-0389

Marx SJ, Aurbach GD, Gavin JR, 3rd, and Buell DW. 1974. Calcitonin receptors on cultured human lymphocytes. J Biol Chem 249:6812-6816.

Morimoto S, Birge SJ, Fausto A, and Avioli LV. 1984. Inhibition of calcitonin secretion by exogenous calcitonin in the rat. Endocrinology 115:60-64. 10.1210/endo-115-1-60

Muff R, Born W, Lutz TA, and Fischer JA. 2004. Biological importance of the peptides of the calcitonin family as revealed by disruption and transfer of corresponding genes. Peptides 25:2027-2038. S0196-9781(04)00364-X [pii]10.1016/j.peptides.2004.08.007

Nakamura M, Han B, Nishishita T, Bai Y, and Kakudo K. 2007. Calcitonin targets extracellular signalregulated kinase signaling pathway in human cancers. J Mol Endocrinol 39:375-384. 39/6/375 [pii]10.1677/JME-07-0036

Ng KW, Livesey SA, Larkins RG, and Martin TJ. 1983. Calcitonin effects on growth and on selective activation of type II isoenzyme of cyclic adenosine 3':5'-monophosphate-dependent protein kinase in T 47D human breast cancer cells. Cancer Res 43:794-800.

Nicholson GC, D'Santos CS, Evans T, Moseley JM, Kemp BE, Michelangeli VP, and Martin TJ. 1988. Human placental calcitonin receptors. Biochem $J$ 250:877-882.

Nicholson GC, Horton MA, Sexton PM, D'Santos CS, Moseley JM, Kemp BE, Pringle JA, and Martin TJ. 1987. Calcitonin receptors of human osteoclastoma. Horm Metab Res 19:585-589. 10.1055/s-20071011887

Orme AL, and Pento JT. 1976. Evidence of calcitonin-induced inhibition of calcitonin secretion in porcine thyroid slices. Proc Soc Exp Biol Med 151:110-112.

Pacini F, Castagna MG, Cipri C, and Schlumberger M. 2010. Medullary thyroid carcinoma. Clin Oncol (R Coll Radiol) 22:475-485. S0936-6555(10)00172-X [pii]10.1016/j.clon.2010.05.002

Pondel M. 2000. Calcitonin and calcitonin receptors: bone and beyond. Int J Exp Pathol 81:405-422.

Poyner DR, Sexton PM, Marshall I, Smith DM, Quirion R, Born W, Muff R, Fischer JA, and Foord SM. 2002. International Union of Pharmacology. XXXII. The mammalian calcitonin gene-related peptides, adrenomedullin, amylin, and calcitonin receptors. Pharmacol Rev 54:233-246.

Rowley DR. 1998. What might a stromal response mean to prostate cancer progression? Cancer Metastasis Rev 17:411-419.

Scheuba C, Kaserer K, Kaczirek K, Asari R, and Niederle B. 2006. Desmoplastic stromal reaction in medullary thyroid cancer-an intraoperative "marker" for lymph node metastases. World J Surg 30:853-859. 10.1007/s00268-005-0391-4

Sexton PM, McKenzie JS, and Mendelsohn FAO. 1988. Evidence for a new subclass of calcitonin/calcitonin gene-related peptide binding sites in rat brain. Neurochem Int 12:323-335. 
476

477

478

479

480

481

482

483

484

485

486

487

488

489

490

491

492

493

494

495

496

497

498

499

500

501

502

503

504

505

506

507

508

509

510

511

512

513

514

515

516

517

518

519

520

521

522

523

Shah GV, Muralidharan A, Gokulgandhi M, Soan K, and Thomas S. 2009. Cadherin switching and activation of beta-catenin signaling underlie proinvasive actions of calcitonin-calcitonin receptor axis in prostate cancer. J Biol Chem 284:1018-1030. M807823200 [pii]10.1074/jbc.M807823200

Silvestris F, Cafforio P, De Matteo M, Quatraro C, and Dammacco F. 2008. Expression and function of the calcitonin receptor by myeloma cells in their osteoclast-like activity in vitro. Leuk Res 32:611-623. S0145-2126(07)00286-X [pii]10.1016/j.leukres.2007.07.009

Tamburrino A, Molinolo AA, Salerno P, Chernock RD, Raffeld M, Xi L, Gutkind JS, Moley JF, Wells SA, Jr., and Santoro M. 2012. Activation of the mTOR pathway in primary medullary thyroid carcinoma and lymph node metastases. Clin Cancer Res 18:3532-3540. 18/13/3532 [pii]10.1158/10780432.CCR-11-2700

Thakkar A, Bijnsdorp IV, Geldof AA, and Shah GV. 2013. Profiling of the calcitonin-calcitonin receptor axis in primary prostate cancer: clinical implications and molecular correlates. Oncol Rep 30:12651274. 10.3892/or.2013.2583

Thomas S, Chigurupati S, Anbalagan M, and Shah G. 2006. Calcitonin increases tumorigenicity of prostate cancer cells: evidence for the role of protein kinase $A$ and urokinase-type plasminogen receptor. Mol Endocrinol 20:1894-1911. me.2005-0284 [pii]10.1210/me.2005-0284

Thomas S, Muralidharan A, and Shah GV. 2007. Knock-down of calcitonin receptor expression induces apoptosis and growth arrest of prostate cancer cells. Int J Oncol 31:1425-1437.

Tikellis C, Xuereb L, Casley D, Brasier G, Cooper ME, and Wookey PJ. 2003. Calcitonin receptor isoforms expressed in the developing rat kidney. Kidney International 63:416-426.

Tlsty TD, and Coussens LM. 2006. Tumor stroma and regulation of cancer development. Annu Rev Pathol 1:119-150. 10.1146/annurev.pathol.1.110304.100224

Tolcos M, Tikellis C, Rees S, Cooper M, and Wookey P. 2003. Ontogeny of calcitonin receptor mRNA and protein in the developing central nervous system of the rat. J Comp Neurol 456:29-38.

Turner AG, Tjahyono F, Chiu WS, Skinner J, Sawyer R, Moore AJ, Morris HA, Findlay DM, Zajac JD, and Davey RA. 2011. The role of the calcitonin receptor in protecting against induced hypercalcemia is mediated via its actions in osteoclasts to inhibit bone resorption. Bone 48:354-361. 10.1016/j.bone.2010.09.013

Wang X, Nakamura M, Mori I, Takeda K, Nakamura Y, Utsunomiya H, Yoshimura G, Sakurai T, and Kakudo K. 2004. Calcitonin receptor gene and breast cancer: quantitative analysis with laser capture microdissection. Breast Cancer Res Treat 83:109-117. 5253733 [pii]10.1023/B:BREA.0000010703.59483.c0

Wimalawansa SJ. 1997. Amylin, calcitonin gene-related peptide, calcitonin, and adrenomedullin: a peptide superfamily. Crit Rev Neurobiol 11:167-239.

Wookey P, Zulli A, Lo C, Hare D, Schwarer A, Darby I, and Leung A. 2010. Calcitonin receptor (CTR) expression in embryonic, foetal and adult tissues: developmental and pathophysiological implications. In: Hay D, and Dickerson I, eds. The calcitonin gene-related peptide family; form, function and future perspectives. Netherlands: Springer, 199-233.

Wookey PJ, McLean CA, Hwang P, Furness SG, Nguyen S, Kourakis A, Hare DL, and Rosenfeld JV. 2012 a. The expression of calcitonin receptor detected in malignant cells of the brain tumour glioblastoma multiforme and functional properties in the cell line A172. Histopathology 60:895-910. 10.1111/j.1365-2559.2011.04146.x

Wookey PJ, Turner K, and Furness JB. 2012b. Transient expression of the calcitonin receptor by enteric neurons of the embryonic and early post-natal mouse. Cell Tissue Res 347:311-317. 10.1007/s00441-011-1303-6

Wookey PJ, Zulli A, Buxton BF, and Hare DL. 2008. Calcitonin receptor immunoreactivity associated with specific cell types in diseased radial and internal mammary arteries. Histopathology 52:605-612. HIS2979 [pii]10.1111/j.1365-2559.2008.02979.x 
524 Wookey PJ, Zulli A, and Hare DL. 2009. The elevated expression of calcitonin receptor by cells recruited 525 into the endothelial layer and neo-intima of atherosclerotic plaque. Histochem Cell Biol 132:181526 189. 10.1007/s00418-009-0600-6

527 Wu G, Burzon DT, di Sant'Agnese PA, Schoen S, Deftos L, Gershagen S, and Cockett AT. 1996. Calcitonin 528 receptor mRNA expression in the human prostate. Urology 47:376-381. S0090429599804567 [pii] 


\section{Table $\mathbf{1}$ (on next page)}

Staining intensity and extension of CTR expression in the 75 MTC cases. 
1 Table 1: Staining intensity and extension of CTR expression in the $75 \mathrm{MTC}$ cases

\begin{tabular}{|c|c|c|c|c|c|}
\hline $\begin{array}{l}\text { Intensity } \\
\text { expression }\end{array}$ & $\mathbf{n}$ & $\%$ & $\begin{array}{c}\text { Cellular } \\
\text { expression \% }\end{array}$ & $\mathbf{n}$ & $\%$ \\
\hline Absent & 11 & $14.7 \%$ & $<5 \%$ & 13 & $17.3 \%$ \\
\hline Faint & 26 & $34.7 \%$ & $5-25 \%$ & 0 & $0 \%$ \\
\hline Moderate & 19 & $25.3 \%$ & $25-50 \%$ & 7 & $9.3 \%$ \\
\hline Strong & 19 & $25.3 \%$ & $50-75 \%$ & 4 & $5.3 \%$ \\
\hline & & & $75-100 \%$ & 51 & $68 \%$ \\
\hline Total & 75 & $100 \%$ & & 75 & $100 \%$ \\
\hline
\end{tabular}

2

3

4 
Table 2 (on next page)

Staining score of CTR IHC in the 75 MTC cases. 
1 Table 2: Staining score of CTR IHC in the 75 MTC cases

2

\begin{tabular}{c|c|c}
\hline CTR Staining Score $^{*}$ & $\mathbf{n}$ & $\%$ \\
\hline $\mathbf{0}$ & 13 & 17,3 \\
$\mathbf{2}$ & 6 & 8 \\
$\mathbf{3}$ & 4 & 5,3 \\
$\mathbf{4}$ & 15 & 20 \\
$\mathbf{8}$ & 18 & 24 \\
$\mathbf{1 2}$ & 19 & 25,3 \\
Total & 75 & $100 \%$ \\
\hline
\end{tabular}

3 * Product of the staining intensity by the proportion of positive cells; scores of 1, 5, 6, 7 , 49,10 and 11 were not obtained in any case. 


\section{Table 3 (on next page)}

Clinicopathological and molecular associations with CTR expression. 
1 Table 2: Clinicopathological and molecular associations with CTR expression

\begin{tabular}{|c|c|c|}
\hline Clinicopathological (N) & $\begin{array}{l}\text { CTR expression } \\
(\text { Mean } \pm \text { SD) }\end{array}$ & p value \\
\hline \multicolumn{3}{|l|}{ Gender } \\
\hline Female (29) & $(6.8 \pm 4.8)$ & 0.044 \\
\hline Male (25) & $(4.4 \pm 3.50)$ & \\
\hline \multicolumn{3}{|l|}{ Tumor size (cm) } \\
\hline$<2(18)$ & $(5.7 \pm 4.6)$ & 0.55 \\
\hline$\geq 2(20)$ & $(4.9 \pm 4.5)$ & \\
\hline \multicolumn{3}{|l|}{ Stroma } \\
\hline Absent (20) & $(7.9 \pm 4.2)$ & 0.042 \\
\hline Present (hyaline) (51) & $(5.6 \pm 4.3)$ & \\
\hline \multicolumn{3}{|l|}{ Amyloid deposits } \\
\hline Absent (14) & $(5.5 \pm 4.2)$ & 0.91 \\
\hline Present (26) & $(5.4 \pm 4.6)$ & \\
\hline \multicolumn{3}{|l|}{ Extrathyroidal Extension** } \\
\hline Absent (7) & 9.5 & 0.42 \\
\hline Present (14) & 11.8 & \\
\hline \multicolumn{3}{|l|}{ Metastasis** } \\
\hline Absent (11) & 15.1 & 0.96 \\
\hline Present (18) & 14.9 & \\
\hline \multicolumn{3}{|l|}{ Invasion (vascular and/or } \\
\hline \multicolumn{3}{|l|}{ capsular)** } \\
\hline Absent (4) & 14.6 & \\
\hline Present (21) & 12.7 & \\
\hline
\end{tabular}


RET

$\begin{array}{lll}\text { Wild type (37) } & (6.65 \pm 4.54) & 0.26\end{array}$

Mutated (38) $\quad(5.53 \pm 4.19)$

$\boldsymbol{R A S}$

Wild type (66) $\quad(6.38 \pm 4.37)$

Mutated (9) $\quad(3.89 \pm 3.88)$

RET or RAS mutation

Wild type (29)

$(7.34 \pm 4.47)$

Mutated (46) *

$(5.28 \pm 4.16)$

0.046

2

** For these variables the Mann-Whitney non parametric test (group $<30$ cases) was used; the

3 CTR protein expression is reported as mean rank.

$4 *$ A case presented a RET and a RAS mutation.

5 


\section{Figure 1}

Calcitonin receptor protein expression.

A and B) Negative control, a MTC case in which the primary antibody was omitted. (C and D) Negative CTR-expression in a case of MTC. (E and F) Positive CTR-expression in a case of MTC (score 2: extent 25-50\%, intensity $1+$ ). (G and H) Positive CTR-expression in a case of MTC (score 12: extent $100 \%$, intensity $3+$ ). The dashed square in $A, B$ and $C$ photomicrographs taken at 10x magnification represents the area in $D, E$ and $F$ pictures taken using the $60 \mathrm{x}$

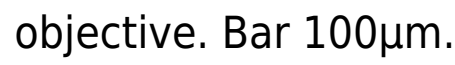



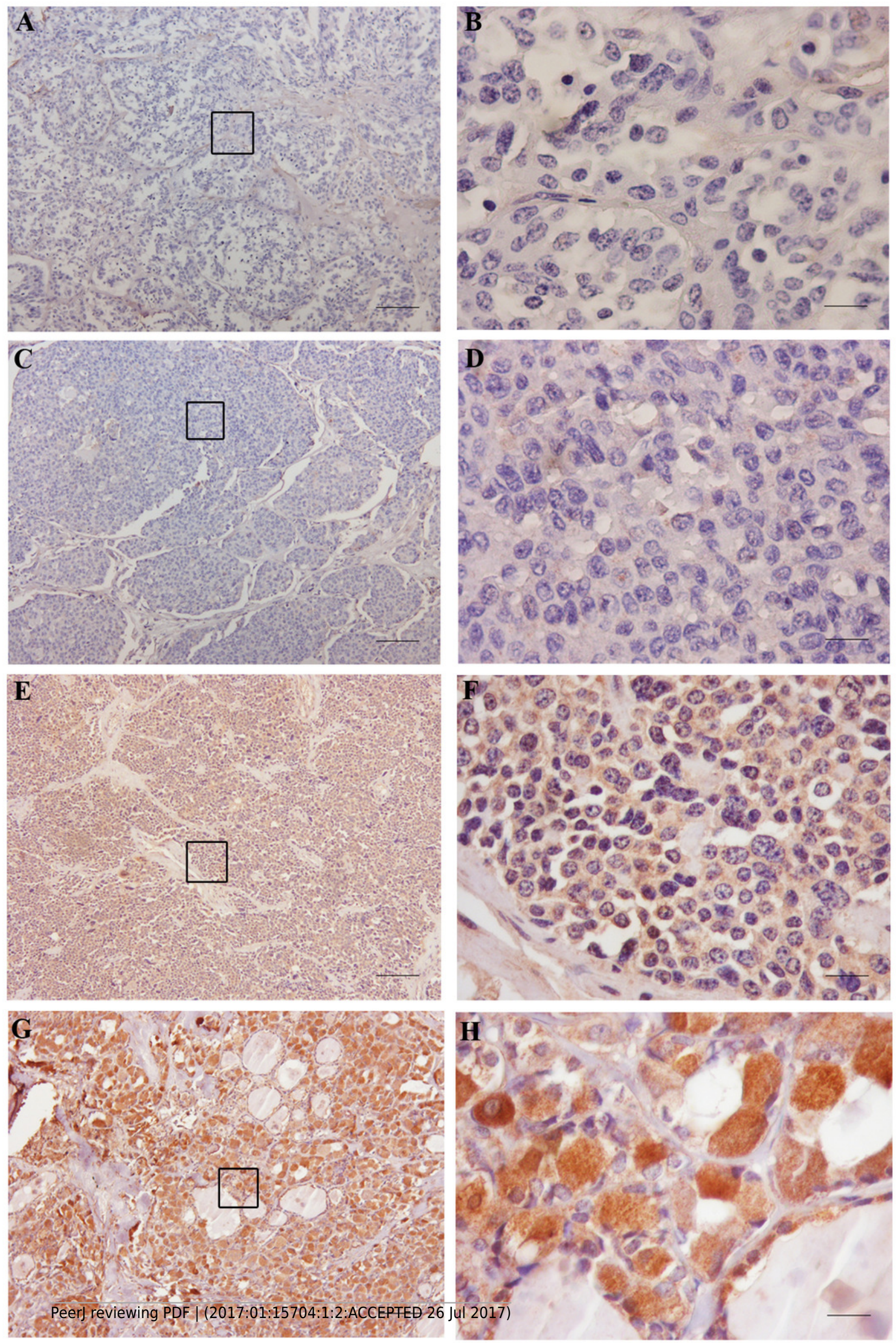
Figure 2

CTR score and CT intensity in the same cases of MTCS.

( $A$ and D) CTR score 0 and CT intensity 1. (B and E) CTR score 4 (extent 75-100\%, intensity 1), CT intensity 3. (C and F) CTR score 12 (extent 75-100\%, intensity 3), CT intensity 4. Note that higher CTR scores correspond to more intense CT immunostainings. Photomicrographs

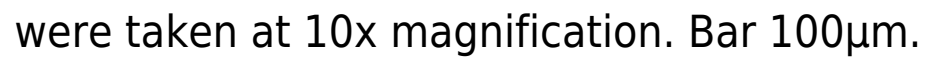
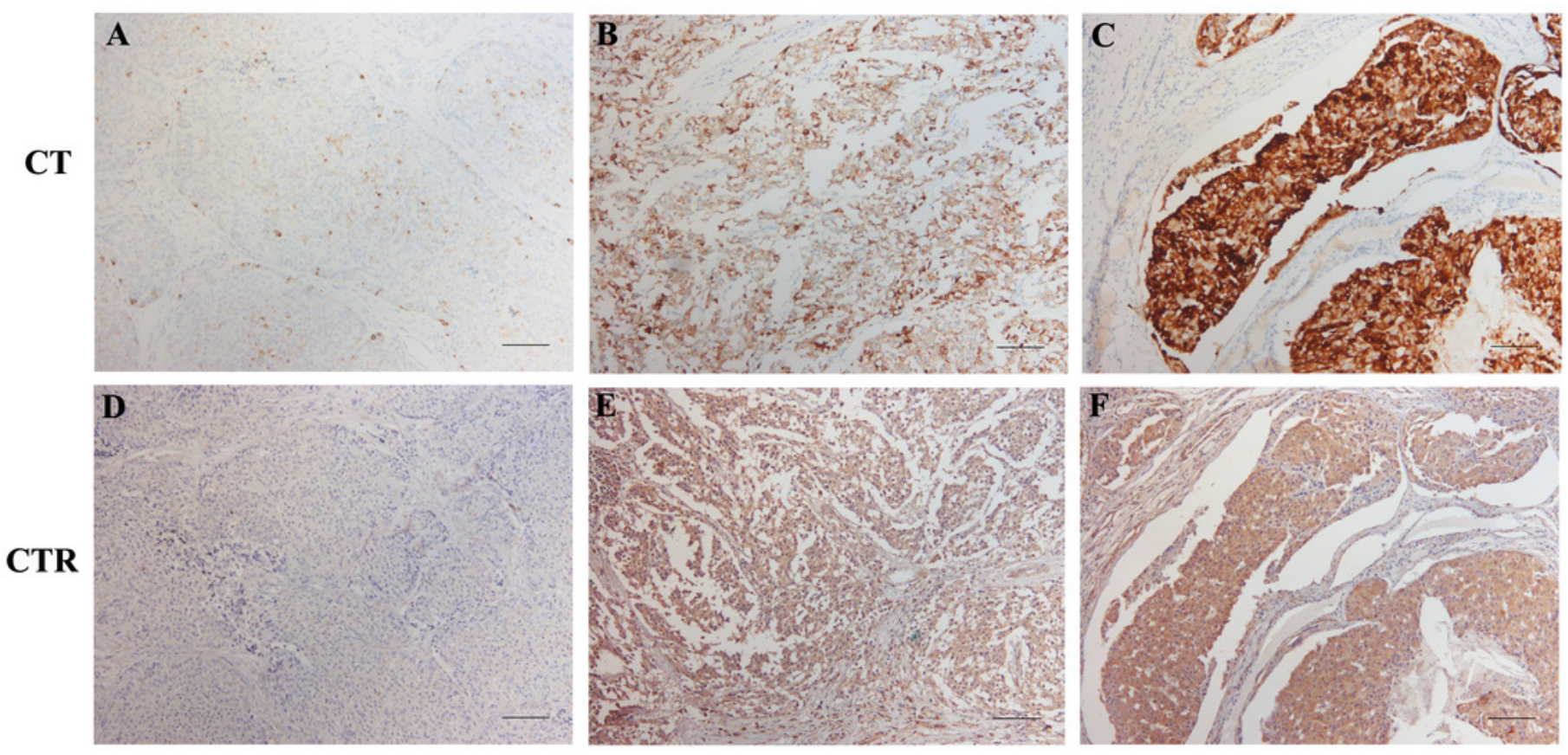
Figure 3

CTR mRNA expression in thyroid tissues and in two MTC cell lines

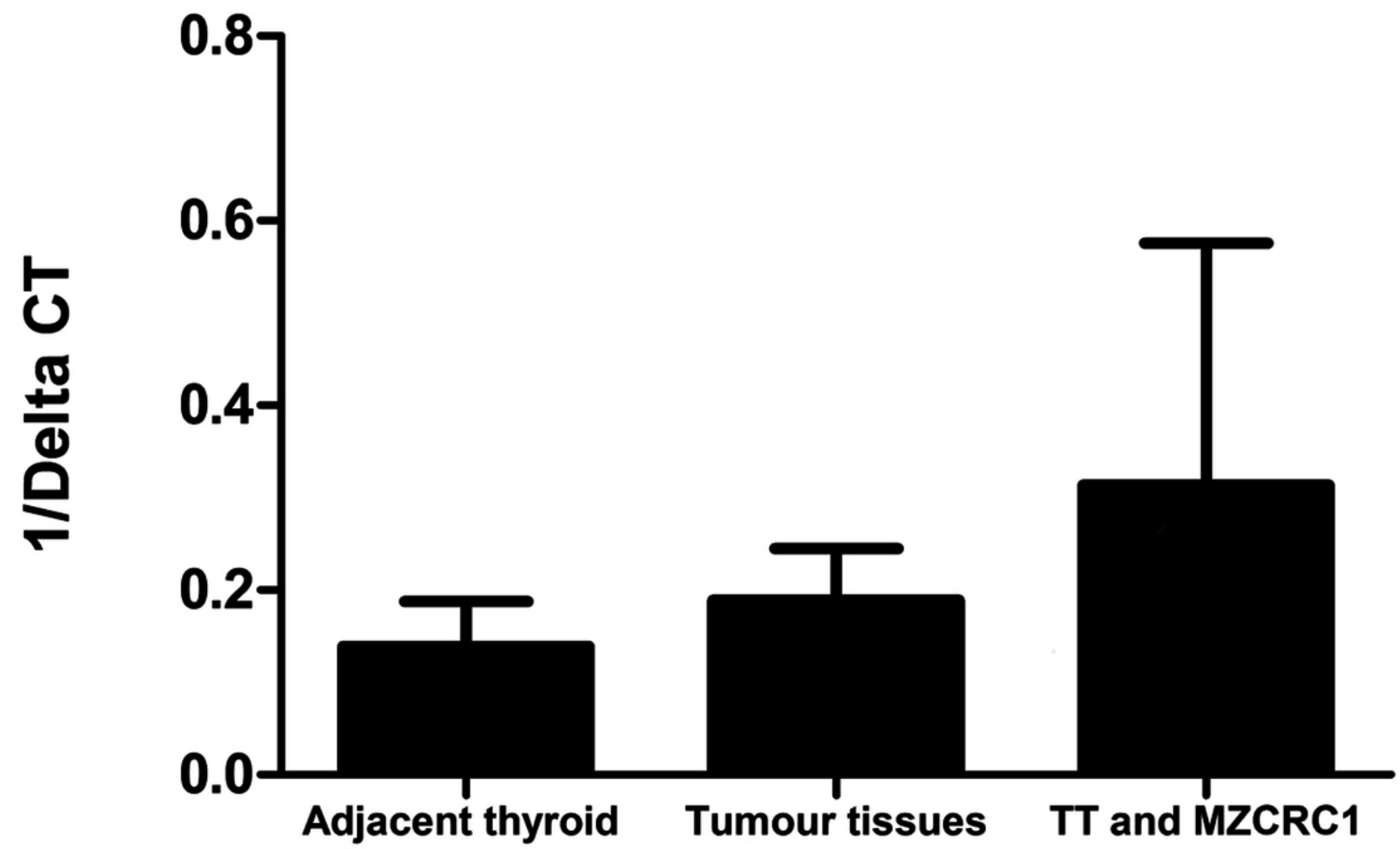

